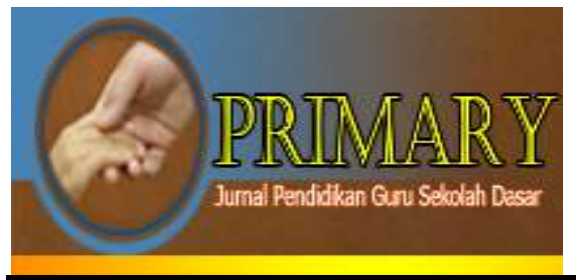
PRIMARY: JURNAL PENDIDIKAN GURU SEKOLAH DASAR VOLUME 10 NOMOR 6 DESEMBER 2021
ISSN : 2303-1514 | E-ISSN : 2598-5949

DOI : http://dx.doi.org/10.33578/jpfkip.v10i6.8638

https://primary.ejournal.unri.ac.id/index.php/JPFKIP

\title{
KEMAMPUAN GURU DALAM MEMBUAT SOAL HOTS DALAM UJIAN TENGAH SEMESTER
}

\author{
Nenny Herawati
}

Sekolah Dasar Negeri 023 Semoga Jaya, Indragiri Hilir, Indonesia

nennyherawati@ymail.com

\section{TEACHERS' ABILITY IN MAKING HOTS QUESTIONS FOR MID-SEMESTER TEST}

\begin{abstract}
ARTICLE HISTORY
ABSTRACT

Submitted:

19 Oktober 2021

$19^{\text {th }}$ October 2021

Abstract: Teachers are an essential key in improving the quality of education. One of the characteristics of good quality education is creating a good learning process, starting from planning, implementation, and evaluation. In line with this, the teachers' ability to evaluate students is needed, one of which is the HOTS question. The HOTS (Higher Order Thinking Skill) question refers to an instrument used to measure higher-order thinking skills, namely the ability to remember and restate or refer without processing. The research used was School Action Research (PTS) using the Kemmis and Mc. Taggart. This research was conducted at SD Negeri 023 Semoga Jaya. The subjects of this research were eight teachers. Two cycles showed an increase in the results of the performance indicator assessment. The average obtained in the first cycle was $<75$, while in the second cycle, the average obtained after more intense actions was $>75$. This result was very satisfying because the teachers understood how to make HOTS questions as learning objectives in the Mid-Semester Exam.
\end{abstract}

Accepted:

05 Desember 2021

$05^{\text {th }}$ December 2021

Published:

27 Desember 2021

$27^{\text {th }}$ December 2021
Keywords: teachers' ability, HOTS, mid-semester test

Abstrak: Guru merupakan kunci penting dalam keberhasilan memperbaiki mutu pendidikan. Salah satu ciri dari mutu pendidikan yang baik adalah terciptanya proses pembelajaran yang baik pula, yaitu mulai dari perencanaan, pelaksanaan maupun evaluasi. Selaras dengan hal ini perlunya kemampuan guru dalam membuat alat untuk mengevaluasi peserta didik salah satunya yaitu soal HOTS. Soal HOTS (Higher Order Thinking Skill) merupakan instrumen pengukuran yang digunakan untuk mengukur kemampuan berpikir tingkat tinggi, yaitu kemampuan yang tidak sekedar mengingat, menyatakan kembali, atau merujuk tanpa melakukan pengolahan. Penelitian yang digunakan adalah Penelitian Tindakan Sekolah (PTS) dengan menggunakan desain penelitian model Kemmis dan Mc. Taggart. Penelitian ini dilaksanakan di SD Negeri 023 Semoga Jaya. Subjek penelitian ini adalah guru, jumlah guru sebanyak 8 orang. Dua siklus yang memperlihatkan hasil penilaian indikator kinerja dengan rata-rata yang meningkat. Siklus I rata-rata yang diperoleh yaitu $<75$, sedangkan pada siklus II rata-rata yang diperoleh setelah melakukan tindakan yang lebih intens $>75$. Hasil ini sangat memuaskan karena guru-guru sudah paham dalam membuat soal HOTS sebagai tujuan pembelajaran yang dilakukan pada Ujian Tengah Semester.

Kata Kunci : kemampuan guru, HOTS, ujian tengah semester

CITATION

Herawati, N. (2021). Kemampuan Guru Dalam Membuat Soal Hots Dalam Ujian Tengah Semester. Primary: Jurnal Pendidikan Guru Sekolah Dasar, 10 (6), 1689-1694. DOI: http://dx.doi.org/10.33578/jpfkip.v10i6.8638 


\section{PENDAHULUAN}

Guru merupakan kunci penting dalam keberhasilan memperbaiki mutu pendidikan. Salah satu ciri dari mutu pendidikan yang baik adalah terciptanya proses pembelajaran yang baik pula, yaitu mulai dari perencanaan, pelaksanaan maupun evaluasi. Selaras dengan hal ini perlunya kemampuan guru dalam membuat alat untuk mengevaluasi peserta didik salah satunya yaitu soal atau tes. Soal atau tes adalah salah satu jenis instrumen yang digunakan untuk mengetahui kemampuan siswa dalam menyerap pelajaran yang diberikan oleh guru. Hal ini sejalan dengan pendapat Indrakusuma (dalam Basuki \& Hariyanto, 2014) menyatakan bahwa "tes adalah suatu alat atau prosedur yang sistematis dan objektif untuk memperoleh data atau keterangan-keterangan yang diinginkan tentang seseorang, dengan cara yang boleh dikatakan tepat dan cepat".

Dalam meningkatkan kualitas berpikir siswa, guru harus menggunakan soal-soal sekolah yang dapat mendukung hal tersebut yaitu dengan mengembangkan penggunaan soal HOTS pada siswa. HOTS akan meningkatkan siswa dalam mengkonstruksi atau menyusun argumen yang tepat dan efektif untuk membuat keputusan atau solusi yang rasional. Menurut Setiawati et al., (2018) soal HOTS (Higher Order Thinking Skill) merupakan intrumen pengukuran yang digunakan untuk mengukur kemampuan berpikir tingkat tinggi, yaitu kemampuan yang tidak sekedar mengingat, menyatakan kembali, atau merujuk tanpa melakukan pengolahan.

Menurut Presseisen (dalam Devi, 2011) menyatakan bahwa "HOTS (High Order Thinking Skills) atau keterampilan berpikir tingkat tinggi dibagi menjadi empat kelompok, yaitu pemecahan masalah, membuat keputusan, berpikir kritis dan berpikir kreatif". Hal ini juga harus dibarengi dengan kemampuan guru dalam membuat soal HOTS. Salah satu kemampuan guru yang harus dimiliki dan menjadi bagian yang paling penting adalah kemampuan membuat dan mengembangkan alat evaluasi hasil belajar siswa. Evaluasi adalah kegiatan mengidentifikasi untuk melihat apakah suatu program yang telah direncanakan telah tercapai atau belum, berharga atau tidak, dan dapat pula untuk melihat tingkat efisiensi pelaksanaannya. Tujuan dari kegiatan evaluasi ini adalah untuk mengetahui apakah tujuan yang telah dirumuskan itu tercapai atau belum dan apakah materi pelajaran yang diajarkan di kelas sudah tepat. Untuk dapat melakukan kegiatan evaluasi, tentu saja dibutuhkan suatu alat. Alat yang digunakan dalam kegiatan evaluasi ini dapat kita sebut sebagai instrumen (Devi, 2011).

Soal atau tes (instrumen) sendiri berfungsi sebagai alat pengukuran terhadap siswa dan alat pengukuran keberhasilan proses belajar mengajar di kelas. Secara umum, tes digolongkan ke dalam beberapa kategori, salah satunya adalah tes sumatif. Tes sumatif ini biasa dilaksanakan diakhir program pengajaran atau dikenal dengan istilah ulangan umum dan Ulangan Tengah Semester (UTS). Tes sumatif bertujuan untuk menentukan nilai yang menunjukkan keberhasilan siswa setelah menempuh proses pembelajaran dalam jangka waktu tertentu, sehingga dapat diketahui siswa tersebut dapat melanjutkan ke pengajaran berikutnya atau tidak (Yuniar, Rakhmat, \& Saepulrohman, 2015).

Berdasarkan pada hasil observasi terhadap guru SD Negeri 023 Semoga Jaya, Kecamatan Kempas, Kabupaten Indragiri Hilir, guru-guru masih belum mampu membuat soal HOTS sendiri. Fakta ini tentunya sangat mengkhawatirkan, karena jika kondisi ini tidak segera diatasi dikhawatirkan akan berdampak pada menurunnya kualitas pembelajaran yang dilaksanakan oleh guru-guru tersebut. Karena dengan menurunnya kualitas pembelajaran di sekolah dikhawatirkan akan menurunkan nilai hasil belajar para siswa, maka perlu dilakukan penelitian tindakan. 
Pada Peraturan Menteri Pendidikan dan Kebudayaan Republik Indonesia No. 54 tahun 2013 dijelaskan bahwa "Standar kompetensi lulusan adalah kualifikasi kemampuan lulusan yang mencakup sikap, pengetahuan, dan keterampilan". Pernyataan tersebut memiliki arti bahwa untuk mengukur pencapaian belajar tidak hanya dipandang dari segi siswa dalam menguasi materi tetapi diukur juga dari segi sikap, pengetahuan, dan keterampilan. Penjelasan tersebut menyatakan bahwa soal yang digunakan untuk Ujian Tengah Semester harus memenuhi tingkat keterbacaan berdasarkan karakteristik soal HOTS, hal tersebut merupakan langkah awal untuk mengoptimalkan tingkat pemikiran peserta didik dan kemampuan guru dalam menjawab dan membuat soal HOTS, selain itu guru bisa mengetahui sejauh mana siswa dalam memahami pelajaran yang sudah diberikan selama setengah semester.

\section{METODE PENELITIAN}

Penelitian Tindakan Sekolah ini dilaksanakan di SDN 023 Semoga Jaya, Indragiri Hilir. Subyek penelitian guru SDN 023 Semoga Jaya, Indragiri Hilir, dengan jumlah guru 8 orang yang terdiri. Waktu Penelitian pada semester I Tahun pelajaran 2020/2021. Penelitian ini dilaksanakan dalam dua siklus dan setiap siklus terdiri dari empat kali pertemuan. Desain penelitian model Kemmis dan Mc. Taggart yaitu berbentuk spiral dari siklus yang satu ke siklus yang berikutnya. Setiap siklus meliputi planning (rencana), action (tindakan), observation (pengamatan), dan reflection (refleksi) (dalam Arikunto, 2002). Teknik pengumpulan data melalui teknik pengamatan dan wawancara. Data dianalisis secara kuantitatif dan disajikan dalam bentuk tabel.

\section{HASIL DAN PEMBAHASAN}

Data penilaian soal Higher order Thinking Skills (HOTS) terhadap delapan orang guru diperoleh informasi bahwa enam orang belum memahami kerangka dan komponenkomponen penyusunan soal Higher order Thinking Skills (HOTS), hanya dua orang guru yang bisa menyusun soal Higher order Thinking Skllis (HOT), kebanyakan guru belum tahu dan belum paham mengembangkan soal Higher order Thinking Skills (HOTS), mereka juga tahu bahwa guru harus menggunakan soal Higher order Thinking Skills (HOTS) dalam melaksanakan proses pembelajaran yang dapat dijadikan acuan/pedoman dalam keberhasilan proses pembelajaran.

\section{Siklus I}

Siklus I merupakan pemberlakuan awal penelitian melalui bimbingan dengan tindakan sekolah. Tindakan siklus ini dilakukan sebagai upaya untuk memperbaiki dan memecahkan masalah yang muncul ketika membuat soal-soal HOTS. Hasil penilaian guru dalam menyusun tes dan mengembangkan butir soal HOTS disesuaikan dengan indikator-indikator dan kompetensi dasar yang telah ditentukan, pada tindakan siklus I dapat dilihat pada tabel di bawah ini.

Tabel 1. Hasil Penilaian Guru pada Indikator Kinerja Pertemuan 1 dan 2

\begin{tabular}{|c|c|c|c|c|c|c|c|c|c|c|}
\hline \multirow[b]{2}{*}{ No } & \multirow[b]{2}{*}{ Indikator Kinerja } & \multicolumn{8}{|c|}{ Nilai/Guru } & \multirow{2}{*}{$\begin{array}{c}\text { Rat } \\
\text { a- } \\
\text { rat } \\
\text { a }\end{array}$} \\
\hline & & 1 & 2 & 3 & 4 & 5 & 6 & 7 & 8 & \\
\hline 1 & Ranah kognitif & 5 & 6.5 & 6 & 5.5 & 7 & 5 & 7 & 6 & 4.5 \\
\hline 2 & Bloom pada level analisis & 6 & 7 & 6 & 5 & 6 & 6 & 5 & 7 & 6.0 \\
\hline 3 & Evaluasi dan mengkreasi & 5 & 5.5 & 6.5 & 7 & 7 & 5 & 6 & 5 & 4.4 \\
\hline 4 & Stimulus & 5.5 & 6.5 & 5 & 5 & 6 & 6 & 7 & 6 & 4.4 \\
\hline
\end{tabular}


5 Kemampuan berfikir kritis

6 Transfer satu konsep ke konsep lain

7 Memproses dan menerapkan informasi

8 Mencari kaitan dari berbagai informasi

9 Menggunakan informasi untuk menyelesaikan masalah

10 Menelaah ide dan informasi secara kritis
Berdasarkan tabel di atas dapat dilihat kemampuan guru dalam membuat soal HOTS masih kurang, karena rata-rata yang diperoleh dari setiap indikator kerja <75. Dalam tahap implementasi tindakan ini peneliti melakukan kegiatan-kegiatan seperti berikut: (1) Kepala sekolah menjelaskan langkah-langkah minimal dari penyusunan soal-soal HOTS; (2) Kepala sekolah meminta guru untuk mengisikan lembar soal-soal HOTS yang telah dipersiapkan sebagai latihan; (3) Kepala sekolah meminta guru untuk menyusun lima soal-soal HOTS dengan diberi kompetensi dasar, indikator, dan materi untuk dikerjakan dalam waktu satu minggu; (4) Guru mempresentasikan soal-soal HOTS yang telah dibuat guru di rumah; (5) Peneliti mengamati dan mencatat hal-hal yang perlu untuk perbaikan butir soal. Pada siklus II peneliti perlu memberikan tindakan lebih intens dari pada siklus I.

$\begin{array}{ccccccccc}6 & 6 & 5 & 7 & 6.5 & 5 & 5.5 & 6 & 4.4 \\ 7 & 6.5 & 5.5 & 6 & 7 & 6 & 5 & 7 & 4.8 \\ 6 & 6 & 5 & 6.5 & 5.5 & 5 & 6 & 7 & 4.4 \\ 5.5 & 5 & 6 & 5 & 5 & 5.5 & 6.5 & 6.5 & 2.6 \\ 6 & 5.5 & 6 & 5.5 & 5.5 & 6.5 & 6 & 7 & 3.1 \\ 5 & 6 & 7 & 6 & 6.5 & 7 & 6 & 5.5 & 4.6 \\ & & & & & & & & \end{array}$

\section{Siklus II}

Dalam tahap implementasi tindakan siklus II ini peneliti melakukan lebih intens dengan melakukan kegiatan-kegiatan seperti berikut: (1) Memberikan feedback dari hasil telaah butir soal; (2) Memberikan penjelasan tentang bagaimana membuat butir soal yang harus sesuai dengan indikator; (3) Memberikan penjelasan tentang bagaimana memilih materi yang ditanyakan yang harus sesuai dengan kompetensi; (4) Memberikan penjelasan tentang bagaimana menyusun pilihan jawaban yang harus homogen dan logis; (5) Memberikan penjelasan tentang bagaimana menuliskan panjang rumusan pilihan jawaban yang harus relatif sama, dan (6) Memberikan penjelasan tentang bagaimana penggunaan bahasa yang dipakai yang harus sesuai dengan kaidah mata pelajaran setiap soal.

Tabel 2. Hasil Penilaian Guru pada Indikator Kinerja Pertemuan 3 dan 4

\begin{tabular}{|c|c|c|c|c|c|c|c|c|c|c|}
\hline \multirow{2}{*}{$\begin{array}{l}\mathbf{N} \\
\mathbf{0}\end{array}$} & \multirow{2}{*}{ Indikator Kinerja } & \multicolumn{8}{|c|}{ Nilai/Guru } & \multirow{2}{*}{$\begin{array}{l}\text { Rata- } \\
\text { rata }\end{array}$} \\
\hline & & 1 & 2 & 3 & 4 & 5 & 6 & 7 & 8 & \\
\hline $\mathbf{1}$ & Ranah kognitif & 8 & 8.5 & 7.5 & 7.5 & 8 & 7 & 7.5 & 7 & 7.6 \\
\hline 2 & Bloom pada level analisis & 7.5 & 7 & 7 & 7.5 & 7.5 & 7 & 8 & 7.5 & 7.4 \\
\hline 3 & Evaluasi dan mengkreasi & 7 & 7.5 & 7.5 & 8 & 7 & 7.5 & 8 & 7.5 & 7.5 \\
\hline 4 & Stimulus & 7 & 8 & 7.5 & 7 & 7.5 & 8.5 & 7 & 8 & 7.6 \\
\hline 5 & Kemampuan berfikir kritis & 7.5 & 8 & 7 & 7.5 & 7 & 8 & 7.5 & 7 & 7.4 \\
\hline 6 & Transfer satu konsep ke konsep lain & 7.5 & 8 & 7.5 & 7 & 7.5 & 7 & 7 & 7.5 & 7.4 \\
\hline 7 & Memproses dan menerapkan informasi & 7 & 7 & 7.5 & 8 & 7 & 7.5 & 7 & 7 & 7.3 \\
\hline 8 & Mencari kaitan dari berbagai informasi & 7.5 & 7.5 & 7 & 8.5 & 7.5 & 8.5 & 7 & 7.5 & 7.6 \\
\hline 9 & $\begin{array}{l}\text { Menggunakan informasi untuk } \\
\text { menyelesaikan masalah }\end{array}$ & 7.5 & 8 & 7 & 7.5 & 8.5 & 7.5 & 7 & 7 & 7.5 \\
\hline 10 & $\begin{array}{l}\text { Menelaah ide dan informasi secara } \\
\text { kritis }\end{array}$ & 7.5 & 7 & 7.5 & 8 & 7 & 7.5 & 8 & 7.5 & 7.5 \\
\hline
\end{tabular}




\section{PRIMARY: JURNAL PENDIDIKAN GURU SEKOLAH DASAR \\ VOLUME 10 NOMOR 6 DESEMBER 2021 \\ ISSN : 2303-1514 | E-ISSN : 2598-5949 \\ DOI : http://dx.doi.org/10.33578/jpfkip.v10i6.8638 \\ https://primary.ejournal.unri.ac.id/index.php/JPFKIP}

Berdasarkan tabel diatas setelah diberikan tindakan yang lebih intens rata-rata pada penilaian setiap indikator kerja meningkat signifikan, hal ini dapat dilihat kemampuan guru dalam membuat soal HOTS sudah lebih baik, karena rata-rata yang diperoleh dari setiap indikator kerja $>75$.

\section{Siklus I}

Kepala sekolah meminta guru untuk mengisikan lembar butir soal yang telah dipersiapkan sebagai latihan. Kemudian meminta guru untuk menyusun lima (5) soalsoal HOTS dengan diberi kompetensi dasar, indikator, dan materi dalam waktu satu minggu. Guru mempresentasikan butir soal yang di hadapan teman-temannya. Peneliti menelaah dan mencatat hal-hal yang perlu untuk perbaikan soal-soal HOTS. Dalam kegiatan ini dilakukan telaah dan pengamatan, telaah ditujukkan kepada butir soal yang disesuaikan dengan indikator kinerja. Dari hasil telaah untuk penyusunan dan pengembagan soal-soal HOTS dari 8 orang guru diperoleh nilai rata-rata $<75$.

Dalam kegiatan pengamatan, kepala sekolah/peneliti mengamati guru dalam mempresentasikan soal-soal HOTS di depan teman-teman. Peneliti mengamati dan mencatat hal-hal yang perlu disampaikan dalam perbaikan butir soal. Dari hasil wawancara dengan guru bahwa dalam pembuatan butir soal mereka merasa terbantu dalam menyusun soal-soal HOTS. Para guru memiliki gambaran dalam penyusunan kisikisi dan pengembangan soal-soal HOTS.

\section{Siklus II}

Siklus II dilakukan pada minggu kedua. Setelah mendapatkan penjelasan lebih detail untuk perbaikan butir soal dari kepala sekolah, para guru memperbaiki dan mempresentasikan kembali dihadapan temantemannya. Dari hasil telaah untuk penyusunan dan pengembangan soal-soal HOTS diperoleh nilai rata-rata $>75$. Hasil ini meningkat dengan signifikan. Para guru di SDN 023 Semoga Jaya dapat dikatakan mampu menyusun soal-soal HOTS setelah diberikan bimbingan melalui tindakan sekolah. Dari hasil wawancara dengan guru bahwa dalam membuat butir soal, mereka merasa paham dan mampu menyusun soal-soal HOTS untuk kompetensi dasarkompetensi dasar selanjutnya. Para guru sudah memiliki gambaran dalam pembuatan soal-soal HOTS.

Selaras dengan penelitian ini Maryani \& Martaningsih (2020) menyatakan bahwa pelatihan penyusunan soal HOTS bagi guru SD mampu memperluas pengetahuan dan skills guru dalam menyusun instrumen penilaian berbasis HOTS. Dalam hal ini HOTS juga sebagai pengukuran sebagai tujuan pembelajaran, Setiawati et al., (2018) mengemukakan bahwa soal HOTS merupakan instrumen pengukuran yang digunakan untuk mengukur kemampuan berpikir tingkat tinggi, yaitu kemampuan yang tidak sekedar mengingat, menyatakan kembali, atau merujuk tanpa melakukan pengolahan. Sedangkan menurut Norris \& Ennis dalam Brookhart, S. M. (2010) kemampuan berpikir HOTS atau tingkat tinggi merupakan berpikir kritis, dalam arti masuk akal, pemikiran reflektif difokuskan pada memutuskan apa yang harus dipercaya atau dilakukan, selain itu kemampuan tingkat tinggi merupakan kemampuan umum lain yang terkadang sebagai tujuan pembelajaran.

Suprananto dalam Ningsih (2018) karakteristik soal HOTS (Higher Order Thinking Skill) yiatu bentuk stimulus, kemampuan berpikir kritis dan kemampuan memecahkan masalah. Karakteristik lain berupa kemampuan berpikir kreatif yang dikemukakan Evans dalam Jazuli (2009).

Menurut Ichsan et al., (2019) keterampilan berpikir kritis adalah kemampuan berpikir peserta didik pada level yang lebih tinggi yang meliputi kemampuan mengevaluasi dan menciptakan inovasi dalam memecahkan suatu masalah. Seorang guru harus mempunyai kemampuan dalam mengembangkan keterampilan berpikir tingkat tinggi. Kemampuan guru meliputi pengetahuan, skills, serta attitude yang harus dipunyai, dihayati, dan dikuasai oleh guru supaya mampu menjalankan tugas-tugas keprofesionalannya (Shabir, 2015). 


\section{PRIMARY: JURNAL PENDIDIKAN GURU SEKOLAH DASAR \\ VOLUME 10 NOMOR 6 DESEMBER 2021 \\ ISSN : 2303-1514 | E-ISSN : 2598-5949 \\ DOI : http://dx.doi.org/10.33578/jpfkip.v10i6.8638 \\ https://primary.ejournal.unri.ac.id/index.php/JPFKIP}

\section{SIMPULAN DAN SARAN}

Kemampuan guru dalam membuat soal HOTS semakin meningkat dari siklus I dan siklus II, hal ini dikarenakan diberi bimbingan dan tindakan yang dilakukan peneliti. Dapat dilihat berdasarkan rata-rata dari siklus I <75 yang mana hal ini karena kurangnya intensitas tindakan yang dilakukan. Namun pada siklus II bimbingan dan tindakan dilakukan lebih intens lagi dan juga memberikan feedback kepada guru-guru sehingga hasil penilaian yang didapatkan dari indikator kerja mencapai rata-rata $>75$, hasil ini sangat memuaskan karena guru-guru sudah paham dalam membuat soal HOTS sebagai tujuan pembelajaran yang dilakukan pada Ujian Tengah Semester.

Saran untuk penelitian selanjutnya, untuk meningkatkan kemampuan guru dalam membuat soal HOTS bukan hanya diberikan bimbingan dan tindakan, dapat juga dilakukan metode yang lebih kreatif untuk sarana guruguru lebih memahami pembuatan soal HOTS.

\section{DAFTAR PUSTAKA}

Arikunto, S. (2002). Prosedur Penelitian Suatu Pendekatan Praktek. Jakarta: Rineksa Cipta.

Basuki, I. \& Hariyanto. 2014. Asesmen Pembelajaran. Bandung: PT. Remaja Rosdakarya

Brookhart, S. M. (2010). How To Assess Higher-Order Thinking Skills In Your Classroom.United States of Amerika: ASCD Member Book

Devi, P.K. (2011). Pengembangan Soal "Higher Order Thinking Skill" dalam Pembelajaran IPA SMP/MTs. Diakses dari.https://www.academia.edu/8337926

Ichsan, I. Z., Sigit, D. V., Miarsyah, M., Ali, A., Arif, W. P., \& Prayitno, T. A. (2019). HOTS-AEP: Higher order thinking skills from elementary to master students in environmental learning. European Journal of Educational Research, 8(4), 935-942. https://doi.org/10.12973/eujer.8.4.935
Jazuli., Akhmad. (2009). Berpikir Kreatif Dalam Kemampuan Komunikasi Matematika. Prosiding Seminar Nasional Matematika dan Pendidikan Matematika. Purwokerto: Program Studi Pendidikan Matematika. hlm. 209-220

Maryani, I., \& Martaningsih, S. T. (2020). Pendampingan Penyusunan Soal Higher Order Thinking Bagi Guru Sekolah Dasar. SOLMA, 09(1), 156-166

Ningsih., Desi Lestari. (2018). Analisis Soal Tipe HOTS Dalam Soal Ujian Nasional (UN) Biologi Sekolah Menengah Atas (SMA). Skripsi FKIP. Program Pendidikan MIPA, Universitas Lampung. Bandar Lampung

Peraturan Menteri Pendidikan Nasional No. 54 tahun 2013 Tentang Standar Kompetensi Kelulusan

Setiawati, wiwik. Dkk. (2018). Buku Penilaian Berorientasi Higher Order Thinking Skill. Jakarta: Direktorat Jendral Guru dan Tenaga Kependidikan Kementrian Pendidikan dan Kebudayaan

Shabir U, M. (2015). Kedudukan Guru Sebagai Pendidik: (Tugas dan Tanggung jawab, Hak dan Kewajiban, dan Kompetensi Guru). AULADUNA, 2(2), 221-232

Yuniar, Maharani. Rakhmat, Cece., \& Saepulrohman, Asep. (2015). Analisis Hots (High Order Thinking Skills) Pada Soal Objektif Tes Dalam Mata Pelajaran Ilmu Pengetahuan Sosial (Ips) Kelas V Sd Negeri 7 Ciamis. Jurnal Ilmiah Pendidikan. 2(2), 187-195. 